$\underline{\text { Original Article }}$

\title{
FLT3 Internal Tandem Duplication and D835 Mutations in Patients with Acute Lymphoblastic Leukemia and its Clinical Significance
}

Ghaleb Elyamany ${ }^{1,2}$, Mohammed Awad ${ }^{2}$, Omar Alsuhaibani ${ }^{2}$, Kamal Fadalla ${ }^{3}$, Omer Al Sharif ${ }^{4}$, Mohammad Al Shahrani ${ }^{4}$, FahadAlabbas $^{4}$ and Abdulaziz Al-Abulaaly ${ }^{3}$

${ }^{1}$ Department of Hematology and Blood Bank, Theodor Bilharz Research Institute.

${ }^{2}$ Dept. of Central Military Laboratory, Prince Sultan Military Medical City, Riyadh, Saudi Arabia.

${ }^{3}$ Dept. of Adult Clinical Hematology and Stem cell Therapy, Prince Sultan Military Medical City, Riyadh, Saudi Arabia

${ }^{4}$ Dept. of Pediatric Hematology/Oncology, Prince Sultan Military Medical City, Riyadh, Saudi Arabia

Correspondence to: Ghaleb Elyamany MD, PhD, FRCPC. Lecturer, Theodor Bilharz Research Institute, Egypt Consultant Hematopathology, Prince Sultan Military Medical City, SA. PO Box 7897, Riyadh 11159, Kingdom of Saudi Arabia. Tel: 00196614777714 extension 28140, FAX 01 4783033. E-mail: ghalebelyamany@yahoo.com

Competing interests: The authors have declared that no competing interests exist.

Published: June 1, 2014

Received: January 9, 2014

Accepted: May 9, 2014

Citation: Mediterr J Hematol Infect Dis 2014, 6(1): e2014038, DOI: 10.4084/MJHID.2014.038

This article is available from: http://www.mjhid.org/article/view/12707

This is an Open Access article distributed under the terms of the Creative Commons Attribution License (http://creativecommons.org/licenses/by/2.0), which permits unrestricted use, distribution, and reproduction in any medium, provided the original work is properly cited.

Abstract. The fms-like tyrosine kinase 3 (FLT3) gene is a member of the class III receptor tyrosine kinase family. Mutations of FLT3 were first described in 1997and account for the most frequent molecular mutations in acute myeloid leukemia.

Currently, there is no published data on FLT3 mutations in Saudi acute lymphoblastic leukemia (ALL) patients.

In this retrospective study, we have examined a cohort of 77 ALL patients to determine the prevalence of FLT3 mutations and the possible prognostic relevance of these mutations in ALL patients. Correlations to other biologic factors such as karyotype, molecular mutations, and leukocyte count were also considered.

FLT3 internal tandem duplication (ITD) mutations and point mutation in tyrosine kinase domain (D835) were analyzed in ALL patients, at diagnosis, by polymerase chain reaction (PCR).

Two cases $(2.6 \%, 2 / 77)$ were positive for FLT3 mutations; one was found to have FLT3/ITD and the other FLT3/D835.

Our findings suggest that FLT3 mutations are not common in Saudi ALL and do not affect clinical outcome.

Introduction. The human fms-like tyrosine kinase 3 (FLT3) gene is located on chromosome 13q12 and encompasses 24 exons. It encodes a membrane-bound glycosylated protein of 993 amino acids with a molecular weight of $158-160 \mathrm{kDa}$, as well as a nonglycosylated isoform of $130-143 \mathrm{kDa}$ that is not associated with the plasma membrane. ${ }^{1}$ The structure of FLT3 is shown in the figure $1{ }^{2}$ 
Figure1. Structure of FLT3 receptor.

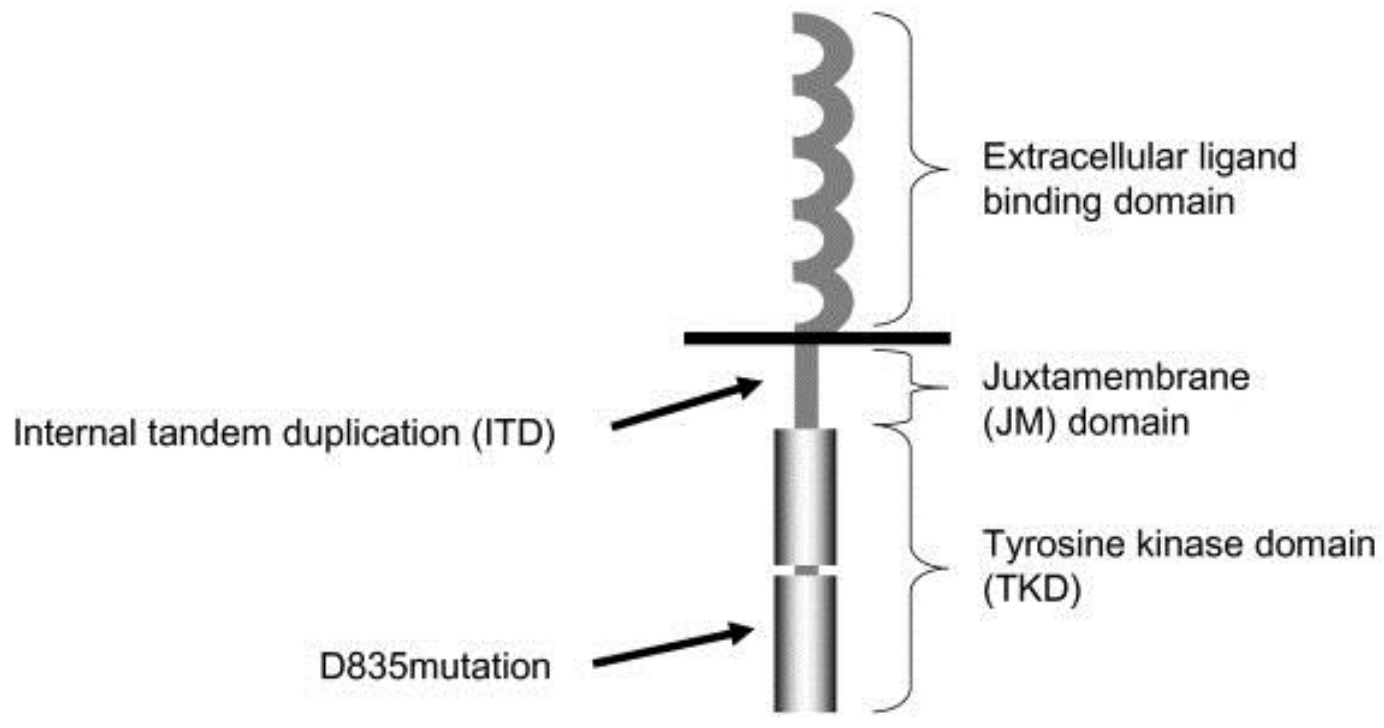

Schematic presentation of the FLT3 receptor (Takahashi S. Journal of Hematology \& Oncology 2011 4:13)

Genomic aberrations of FLT3, including internal tandem duplication (ITD) and point mutations, have been demonstrated in approximately $25-35 \%$ of adults with acute myeloid leukemia (AML) ${ }^{3-7}$ ITD of the FLT3 gene is common in AML and is associated with a bad prognosis and poor response to chemotherapy. Single base mutations at the FLT3 tyrosine kinase domain (TKD), which frequently involves aspartic acid 835 of the kinase domain (D835), leads to a gain of function; however, due to its rarity, its prognostic significance is not well defined. ${ }^{8}$

FLT3 is rarely mutated in leukemic lymphoblasts in adult and pediatric ALL; $;^{3,4,9,10}$ however, FLT3 mutations are relatively common among the cytogenetic subgroups of hyperdiploidy and mixedlineage leukemia (MLL) translocation. ${ }^{11}$

Recent studies have indicated a low overall frequency in childhood ALL (in the 1-8\% range) while consistently demonstrating a higher incidence among those with MLL gene rearrangement and high hyperdiploidy. ${ }^{13-17}$ In adult ALL, FLT3 mutations are even rarer. ${ }^{18}$

While there have been several studies ${ }^{19-27}$ describing activating mutations of the FLT3 gene in AML, there has been little work on these mutations in ALL.

In this study, we analyzed the prevalence of the two types of FLT3 activating mutations in 77 patients with ALL and its prognostic significance. No data currently exist regarding FLT3 mutations in Saudi ALL patients and this study is the first one conducted in Saudi Arabia describing FLT3 mutations in ALL patients.

\section{Material and Methods.}

Study Group: A retrospective review of both adult and pediatric (ages 1 to 15) cases of ALL was performed. Data was obtained from the files of the Department of Hematopathology, Prince Sultan Military Medical City, Saudi Arabia from 2005 to 2013. Leukemia samples were obtained from either bone marrow (BM) or peripheral blood $(\mathrm{PB})$, at diagnosis, from patients with ALL (70 BM samples and 7 PB samples). The peripheral blood samples all had more than $15 \%$ blasts at diagnosis. Five samples obtained from normal bone marrow healthy donors were screened for FLT3 mutations as a reference group. Among the 77 patients, with an established diagnosis by cell morphology and flow cytometric immunophenotyping, 48 were pediatric (62.3\%), 29 were adult (37.7\%), in total, 45 of the patients were male $(58.4 \%)$ and 32 female (41.6\%) Table 1.

Samples were evaluated in addition to cytomorphology, and multiparameter flow cytometry, by cytogenetics, fluorescence in situ hybridization (FISH), and molecular genetics in parallel.

Pediatric patients were treated according to the UKALL 2003 chemotherapy protocol. Initially, eligible pediatric patients were stratified into three risk groups, standard risk (22 patients), intermediate risk (14 patients) and high risk (12 patients) based on age, WBC at presentation, immunophenotype and cytogenetic abnormalities.

Treatment of adult ALL patients was divided into two age groups. Patients at 20 years of age or less were treated according to the Dana-Farber Cancer Institute All Consortium Protocol $00-01^{28}$ and patients over 20 years of age were treated with Hyper-CVAD chemotherapy ${ }^{29}$ At first, risk groups at diagnosis were 
Table 1. Clinical characteristics and cytogenetic findings of the patients included in the study.

\begin{tabular}{|c|c|c|}
\hline Parameter & $\begin{array}{c}\text { Pediatric } \\
\text { ALL } \\
(\mathrm{n}=48) \\
\end{array}$ & $\begin{array}{l}\text { Adullt ALL } \\
\qquad(n=29)\end{array}$ \\
\hline Male:Female & 28:20 & $17: 12$ \\
\hline Median age (years) & $5(1-14)$ & $31.5(17-81)$ \\
\hline Median WBCs Count $\left(\times 10^{9} / \mathrm{L}\right)$ & 10.500 & 16.000 \\
\hline Median Platelets Count ( x10 $/ \mathrm{L})$ & 37.000 & 30.500 \\
\hline Median $\mathrm{Hb}$ (x gm/dl) & 8.2 & 9.8 \\
\hline Median BM Blasts & $90 \%$ & $70 \%$ \\
\hline Median PB Blasts & $40 \%$ & $32 \%$ \\
\hline 5-year survival rate & $82 \%$ & $37 \%$ \\
\hline \multicolumn{3}{|l|}{ FLT3 mutations Rate } \\
\hline FLT3 -ITD & $1 / 48(2.1 \%)$ & $0 / 29(0 \%)$ \\
\hline FLT3-D835 & $1 / 48(2.1 \%)$ & $0 / 29(0 \%)$ \\
\hline Total & $2 / 48(4.2 \%)$ & $0 / 29(0 \%)$ \\
\hline \multicolumn{3}{|l|}{ Cytogenetic Analysis } \\
\hline $\begin{array}{l}\begin{array}{l}\text { Karyotype } \\
\text { (Available) }\end{array} \\
\end{array}$ & $\begin{array}{c}20 \text { normal } \\
8 \text { abnormal }\end{array}$ & $\begin{array}{c}11 \text { normal } \\
7 \text { abnormal }\end{array}$ \\
\hline Available for Fish & $\mathrm{n}=48$ & $\mathrm{n}=28$ \\
\hline $\mathrm{t}(9 ; 22)$ & $4(8.3 \%)$ & $6(21.4 \%)$ \\
\hline $\mathrm{t}(12 ; 21)$ & $6(12.6 \%)$ & $0(0 \%)$ \\
\hline MLL & $4(8.3 \%)$ & $1(3.6 \%)$ \\
\hline MYC & $1(2.1 \%)$ & $1(3.6 \%)$ \\
\hline $\mathrm{t}(1 ; 19)$ & $1(2.1 \%)$ & $1(3.6 \%)$ \\
\hline+21 & $6(12.6 \%)$ & $0(0 \%)$ \\
\hline Del 12p & $2(4.2 \%)$ & $0(0 \%)$ \\
\hline+9 & $2(4.2 \%)$ & $1(3.6 \%)$ \\
\hline+8 & $1(2.1 \%)$ & $0(0 \%)$ \\
\hline-19 & $2(4.2 \%)$ & $1(3.6 \%)$ \\
\hline Hyperdiploid & $3(6.3 \%)$ & $3(10.7 \%)$ \\
\hline tetraploidy & $1(2.1 \%)$ & $0(0 \%)$ \\
\hline Other aberrations & $3(6.3 \%)$ & $2(7.1 \%)$ \\
\hline
\end{tabular}

categorized into a standard risk (15 patients) and high risk (14 patients) to determine the intensity of therapy. This study was approved by the Research and Ethics Committee at this institution.

Morphologic Analysis: For each case in this study, Wright-Giemsa-stained peripheral blood and bone marrow aspirate smears were reviewed. Aspirate clot and biopsy specimens were fixed in formalin, routinely processed and the histologic sections were stained with Hematoxylin and Eosin and reviewed.

Flow CytometricImmunophenotypic Methods: All samples were assessed by multicolor flow cytometry using a large panel of antibodies, including CD2, cytoplasmic and surface CD3, CD4,CD5, CD7, CD8,
CD10, CD19,CD20, CD22, cytoplasmic CD79a, CD13, CD15, CD33, CD11c, CD14, CD64, CD38, CD34, CD117, cytoplasmic terminal deoxynucleotidyltransferase (TdT), and myeloperoxidase (MPO). Antigens were scored as positive using a cutoff of $20 \%$ or more leukemic blasts staining brighter than an isotype-matched negative control.

\section{Molecular Methods:}

1- $\quad$ Analysis of FLT3-ITD mutation. DNA was extracted using a QIAamp DNA Kit (Qiagen) according to the manufacturer's recommendations.

PCR amplification was composed of 200ng of DNA, 50mM KCL, $10 \mathrm{mM}$ Tris-HCL, pH8.3, $1.5 \mathrm{mM}$ MgCL2, 0.001\%(wt/vol) gelatin, $200 \mu \mathrm{M}$ dNTPs, $0.4 \mu \mathrm{M}$ of each primer (5'GCAATTTAGGTATGAAAGCCAGC-3' and ' ${ }^{\prime}$ 'CTTTCAGCATTTTGACGGCAACC-3'), and $1 \mathrm{U}$ of gold Taq polymerase, in a volume of $50 \mu 1^{23}$

The PCR consisted of an initial incubation step at $95^{\circ} \mathrm{C}$ for 10 minutes followed by 35 cycles at $94^{\circ} \mathrm{C}$ for 30 seconds, $57^{\circ} \mathrm{C}$ for 60 seconds, and $72^{\circ} \mathrm{C}$ for 90 seconds. The final extension step was at $72^{\circ} \mathrm{C}$ for 10 minutes on a GeneAmp PCR system 9700(Applied Biosystems). PCR products were analyzed on standard $3 \%$ agarose gels. Normal amplification generates a $330 \mathrm{bp}$ product; whereas, FLT3 ITD mutations (FLT3/ITD+) show longer PCR products.

2- $\quad$ Analysis of the FLT3- D835 mutation. PCR amplification was set up as above using specific primers $^{4}$ for exon 20 (5'CCGCCAGGAACGTGCTTG-3' and 5'GCAGCCTCACATTGCCCC-3'). PCR product was digested with EcoRV (Promega), at $37^{\circ} \mathrm{C}$ for $2 \mathrm{~h}$. The digestion products were separated on a $3 \%$ agarose gel, and incomplete digestion indicated the presence of mutant.

Statistical analysis: The Kaplan-Meier technique was used to analyze the probability of overall survival (OS). OS was calculated from time of diagnosis to death. Continuous variables, such as white blood cell count and hemoglobin, were compared using the KruskalWallis test. Differences between means were considered as significant at $\mathrm{P}<0.05$.

Complete remission (CR) was defined by less than $5 \%$ blast cells in a normocellular marrow and peripheral blood neutrophil count equal to or greater than $1.5 \times 10^{9} /$ liter with a platelet count of more than $100 \times 10^{9} /$ liter. Normalization of cytogenetic abnormalities was not a prerequisite for CR. 
Results. Clinical characteristics at presentation and cytogenetic analysis of the patients in the studied group are summarized in table $\mathbf{1 .}$

In total, the patient age range was 1 to 81 years with a median of 15 years. Pediatric patients were defined as less than 15 years of age. Of the 77 patients, 48 were pediatric (62.3\%), all with de novo ALL (42 cases BALL and 6 cases T-ALL). 29 were adult patients $(37.7 \%)$ in which there were 27 cases of de novo ALL ( 22 cases B-ALL and 5 cases T-ALL) and 2 cases of CML transforming to ALL. Two cases from the pediatric group were diagnosed as biphenotypic leukemia. In total, 45 of the patients were male (58.4\%) and 32 female (41.6\%).

Two of the 77 ALL patients examined showed FLT3 mutations (2/77) with an overall prevalence of 2.6\%. Positive FLT3 mutation patients were both pediatric, one male and one female. One was found to have FLT3/ITD and the other was positive for FLT3/D835 (Figure 2). None of the adult ALL patients was positive for FLT3 mutations. None of the T-ALL (T-ALL - 11/77) and CML patients transforming to ALL showed FLT3/ITD or D835 mutations. None of the patients had a combination of FLT3/ITD and D835 mutation in the FLT3 gene.

The FLT3/ITD positive patient (male, 14 years old) showed a WBC of $91 \times 10^{9} /$ liter with $70 \%$ of the peripheral blasts. The bone marrow (BM) blasts were 95\% and showed a good response to chemotherapy resulting in CR. The FLT3/D835 positive patient (female, 4 years old) showed a WBC of $4.6 \times 10^{9} /$ liter with $32 \%$ of peripheral blasts. The bone marrow (BM) blasts were $95 \%$, and continuous complete remission (CCR) was achieved after chemotherapy.
Cytogenetic and molecular studies revealed that the FLT3/D835 positive patient was hyperdiploidy and reported as $54, \mathrm{XX},+2,+4,+8,+14,+16,+20,21,+21$.nuc ish (ABL1,BCR) X2[100]/ (ETV6,RUNX1)x3[95/100]/(5'MLL,3'MLL,5'MLL con 3'MLL)x2[100]/(5'MYC.3'MYC,5'MY con 3'MYC)x3 [95/100]/ (TCF3,PBX1)x2[100]. An extra copy of chromosome 2, 4, 8, 12,14,16, 20 and 21 was detected in $95 \%$ of the studied cells. Cytogenetic analysis could not be performed due to an insufficient number of metaphases.

Discussion. FLT3 gene mutations, particularly ITD in AML, are well established as the most frequent somatic alterations in AML. A poor prognosis is associated with FTL3 gene mutations in AML and they are found in approximately $5-15 \%$ of children and $25-35 \%$ of adults with AML. ${ }^{4,7,19,20,23,31}$ FLT3 mutations are also found in adult and pediatric ALL, but are much rarer than in AML. ${ }^{3,4,9,10}$ FLT3 is overexpressed at the level of RNA and protein in most B lineage and acute myeloid leukemias. It is also overexpressed in a smaller subset of T-ALL and chronic myeloid leukemias (CML) in blast crisis. ${ }^{32}$

This study is the first to report FLT3 mutations on ALL patients in Saudi Arabia. The overall rate of patients with ALL and FLT3 mutations, in this study, was $2.6 \%$ which is comparable with previously published reports. ${ }^{4,14,33,34,35}$

The incidence of FLT3 mutations in pediatric ALL of this study was $4.2 \%(2 / 48)$. The results are within the range of similar studies conducted in different geographic regions (see table 2).

The incidence of FLT3 mutations in pediatric leukemia is of particular interest due to the several

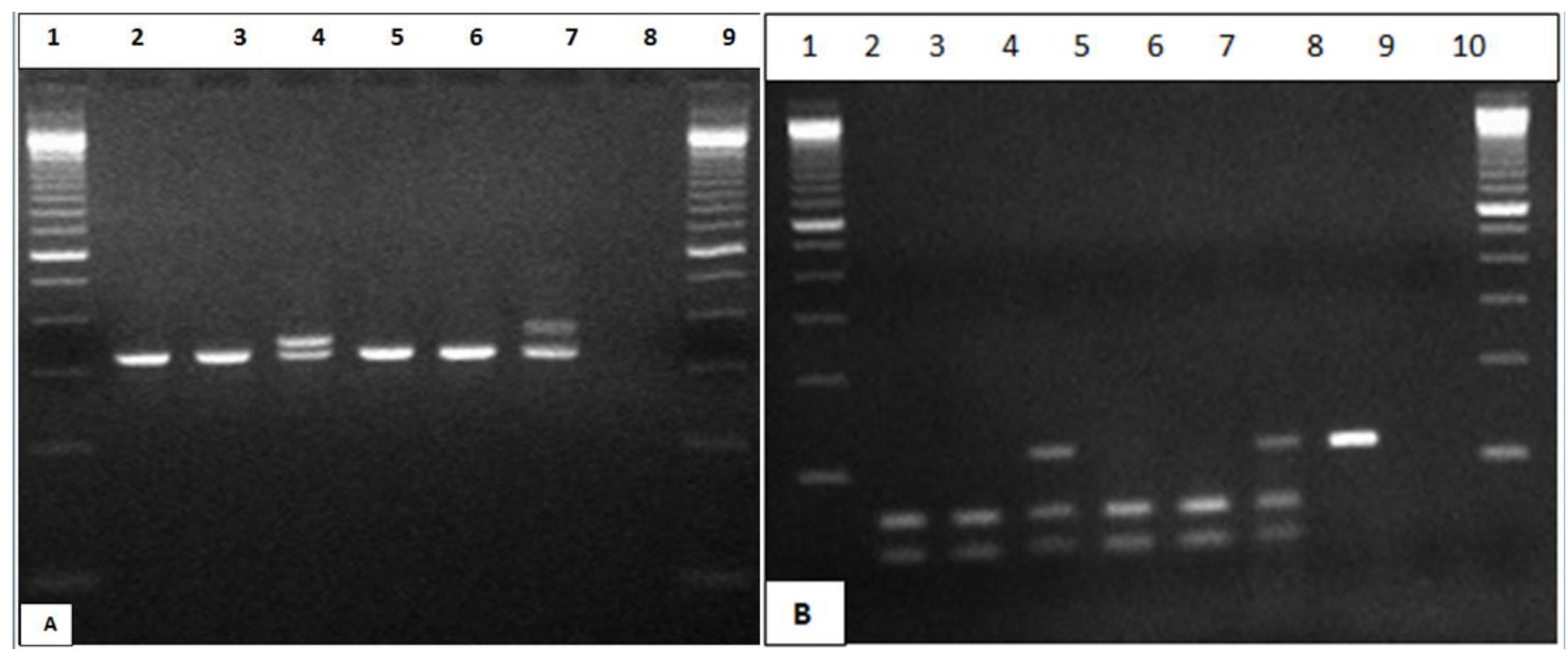

Figure 2. PCR analysis of FLT3-ITD and D835 mutations. A) Agrose gel shows patients positive for ITD lanes 4, patients negative for ITD lanes 2, 3, 5, 6, positive control lane 7, no template control lane 8, Marker lane 1, 9. B) Agrose gel shows digested sample for D835 lanes 27, positive patients lane 4 (114bp, $68 \mathrm{bp}, 49 \mathrm{bp})$, negative patients lanes 2, 3, 5, 6 (68bp, 49bp), positive control lane 7, Undigested sample lane 8 (114bp), no template control lane 9, Marker lanes 1, 10. 
Table 2. Frequency of FLT3 mutations in ALL patients in the current study and in previous studies.

\begin{tabular}{|c|c|c|c|c|c|}
\hline $\begin{array}{c}\text { No. of ALL } \\
\text { Cases }\end{array}$ & $\begin{array}{c}\text { Mutation } \\
\text { number }\end{array}$ & $\begin{array}{c}\text { Mutation } \\
(\%)\end{array}$ & Type of mutation & Comments & Reference \\
\hline 77 & 2 & $2.6 \%$ & ITD and D835 & $\begin{array}{l}\text { No prognostic significance value, } \\
\text { associated with hyperdiploidy }(1 / 6)\end{array}$ & Current Study \\
\hline \multirow{2}{*}{90} & 2 & $2.2 \%$ & ITD & \multirow{2}{*}{ Adult T-ALL } & \multirow{2}{*}{ Grossmann et al, 2013 (37) } \\
\hline & 1 & $1.1 \%$ & TKD & & \\
\hline 25 & 1 & $4 \%$ & ITD & No significant Prognostic value & Ishfaq et al, $2012(38)$ \\
\hline 441 & 9 & $2 \%$ & $\begin{array}{l}2 \text { FLT3 ITDs, one } \\
\text { deletion mutation, } \\
\text { and } 6 \text { point } \\
\text { mutations }\end{array}$ & $\begin{array}{l}\text { Pediatric group, more common in } \\
\text { patients with high hyperdiploidy }\end{array}$ & Chang et al, 2010 (36) \\
\hline 80 & 6 & $7.5 \%$ & 6 ITD, 0 TKD & $\begin{array}{c}\text { Pediatric group, no prognostic } \\
\text { difference between FLT3+ and } \\
\text { FLT3- }\end{array}$ & Karbacak et al, 2010 (35) \\
\hline 83 & 2 & $2.4 \%$ & 2 D835, 0 ITD, & No Prognostic significance & Wang et al, $2010(31)$ \\
\hline 86 & 2 & $2.3 \%$ & $2 \mathrm{AL}$ & $\begin{array}{l}\text { Pediatric group, Co-Presence of } \\
\text { RAS mutations, high frequency in } \\
\text { Hyperdiploid Cases }(2 / 9)\end{array}$ & Braoudaki, 2009 (17) \\
\hline 61 & 3 & $4.9 \%$ & 2 ITD, 1 TKD & & Zhao et al, 2009 (39) \\
\hline 133 & 4 & $3 \%$ & 3 ITD, 1 D835 & $\begin{array}{c}\text { Pediatric group, } 86 \text { de novo ALL ,37 } \\
\text { relapsed ALL } \\
\end{array}$ & Case M, 2008 (14) \\
\hline 25 & 0 & $0 \%$ & - & Pediatric group & Al-Tonbary, 2008 (40) \\
\hline \multirow[b]{2}{*}{143} & 8 & \multirow[b]{2}{*}{$8 \%$} & $2 \% \mathrm{ITD}, 6 \% \mathrm{TKD}$ & \multirow{2}{*}{$\begin{array}{c}0 \% \text { in T-ALL(15), } 128 \text { (B-ALL) } \\
\text { Pediatric group, High in } \\
\text { Hyperdiploid }\end{array}$} & \multirow{2}{*}{ Andersson et al, 2008 (13) } \\
\hline & & & & & \\
\hline 95 & 1 & $1 \%$ & ITD & Pediatric group & Yamamoto et al, 2006 (16) \\
\hline 27 & 0 & $0 \%$ & - & 25 ALL, 2 biphenotypic leukemia & Wang et al, 2005 (41) \\
\hline 63 & 2 & $3.2 \%$ & ITD & $\begin{array}{c}2 \text { cases were Biphonotypic } \\
\text { leukemia, associated with Poor } \\
\text { Prognosis }\end{array}$ & $\mathrm{Xu}$ et al, 2005 (32) \\
\hline 162 & 14 & $9 \%$ & No ITD, 14 TKD & $\begin{array}{l}\text { Pediatric group, high frequency in } \\
\text { hyperdiploidy and MLL gene }\end{array}$ & Taketani et al, 2004 (34) \\
\hline 55 & 3 & $5.5 \%$ & $2 \mathrm{ITD}, 1 \mathrm{TKD}$ & $\begin{array}{c}\text { Adult T-ALL , } 3 \text { cases expressed } \\
\text { CD117 } \\
\end{array}$ & Paietta et al , 2004 (18) \\
\hline 36 & 1 & $2.8 \%$ & TKD & - & Yamamoto et al, 2001 (4) \\
\hline 60 & 2 & $3.3 \%$ & ITD & $\begin{array}{l}2 \text { cases were Biphenotypic, no } \\
\text { prognostic value }\end{array}$ & Xu et al, 1999 (33) \\
\hline 55 & 0 & $0 \%$ & - & - & Yokota et al, 1997 (19) \\
\hline 50 & 0 & $0 \%$ & - & - & Nakao et al, 1996 (42) \\
\hline
\end{tabular}

promising FLT3 inhibitors currently under development. ${ }^{45}$

The frequency of both ITD and D835 mutations among adult ALL patients in this study was $0 \%(0 / 29)$; other studies have reported similar results, ${ }^{19,43,44}$ however, a few studies have reported FLT3 mutations among adult ALL patients at a very low frequency. ${ }^{18}$ As this is a rare occurrence, the limited sample size of this study is the most likely cause of the difference. Similarly, neither FLT3/ITD nor FLT3/D835 mutations were evident in any case of CML transforming to ALL or in T-All (0/11) which is consistent with the study by Anderson et al. 2008 (0\% in 15 T-ALL patients). ${ }^{13}$ Some larger studies have reported a low frequency of
FLT3/ITD and/or FLT3/D835 mutations ranging from $3.3 \%$ to $5.5 \%$ among T-ALL patients. ${ }^{18,39,46}$

In this study, one patient (male, 14 years old) was found to have the FLT3/ITD mutation. He showed leukocytosis and a high blast cell count in PB and BM. This patient exhibited a good response to chemotherapy and achieved complete remission, which is in-line with results of previous studies. ${ }^{35,37,39}$ This patient was also positive for myeloid antigen expression and was diagnosed as acute mixed-lineage leukemia (biphenotypic leukemia). This observation was reported in other studies ${ }^{17,34,35}$ which indicates a higher frequency among the biphenotypic group. 
Cytogenetic analysis could not be performed due to the low number of metaphases.

The other FLT3 mutation patient in this study (female, 4 years old), was found to the FLT3/D835 mutation with no leukocytosis; however, she did show a high blast count in PB and BM. Cytogenetic and molecular studies revealed no association with balanced translocations or MLL gene rearrangement; however, hyperdiploidy (extra copy of chromosome 2 , $4,8,12,14,16,20$ and 21 ) was detected in $95 \%$ of the studied cells. This finding represents a $16.7 \%$ incidence of hyperdiploidy in ALL (1/6) cases. Our results reinforced previous observations, Armstrong et al. $2004,{ }^{12}$ in that the presence of the FLT3 mutation in hyperdiploid ALL did not affect the clinical outcome as the patient responded well to chemotherapy and achieved continuous complete remission (CCR).

In both cases, molecular studies using polymerase chain reaction (PCR) were negative for Philadelphia chromosome $[\mathrm{t}(9 ; 22)(\mathrm{q} 34.1 ; \mathrm{q} 11.2)]$.

The only notable difference between this study and previous studies ${ }^{11,12,36}$ is the lack of association between the high frequency of FLT3 mutation and MLL gene rearrangement. The small sample size (5 ALL patients) is the most likely cause of the difference.

\section{References:}

1. Markovic A, MacKenzie KL, Lock RB: FLT-3: a new focus in the understanding of acute leukemia.Int J Biochem Cell Biol 2005, 37:1168-1172 http://dx.doi.org/10.1016/j.biocel.2004.12.005 PMid:15778081

2. Takahashi S. Downstream molecular pathways of FLT3 in the pathogenesis of acute myeloid leukemia: biology and therapeutic implications. J Hematol Oncol. 2011 Apr 1;4: 13. http://dx.doi.org/10.1186/1756-8722-4-13 PMid:21453545 PMCid:PMC3076284

3. Gilliland DG, Griffin JD. The roles of FLT3 in hematopoiesis and leukemia. Blood 2002 Sep 1; 100(5): 1532-42. http://dx.doi.org/10.1182/blood-2002-02-0492 PMid:12176867

4. Yamamoto Y, Kiyoi H, et al. Activating mutation of D835 within the activation loop of FLT3 in human hematologic malignancies. Blood 2001; 97: 2434-2439. http://dx.doi.org/10.1182/blood.V97.8.2434 PMid:11290608

5. Kiyoi H, Towatari M, Yokota S, Hamaguchi M, Ohno R, Saito H and Naoe T. Internal tandem duplication of the FLT3 gene is a novel modality of elongation mutation which causes constitutive activation of the product. Leukemia 1998; 12: 1333-1337. http://dx.doi.org/10.1038/sj.leu.2401130 PMid:9737679

6. Levis $M$ and Small D. FLT3: ITD does matter in leukemia. Leukemia 2003; 17: 1738-1752. http://dx.doi.org/10.1038/sj.leu.2403099 PMid:12970773

7. Stirewalt DL, Radich JP: The role of FLT3 in haematopoietic malignancies. Nat Rev Cancer 2003; 3(9):650-665. http://dx.doi.org/10.1038/nrc1169 PMid:12951584

8. Leung AY, Man CH, Kwong YL. FLT3 inhibition: a moving and evolving target in acute myeloid leukaemia. Leukemia. 2013 Feb;27(2):260-8. http://dx.doi.org/10.1038/leu.2012.195 PMid:22797419

9. Xu F, Taki T, Eguchi M, et al. Tandem duplication of the FLT3 gene is infrequent in infant acute leukemia. Leukemia. 2000;14:945-947. http://dx.doi.org/10.1038/sj.leu.2401760 PMid:10803532
Neither ITD's or D835 mutations were detected in the healthy donors of this study, and this is consistent with previously reported data. ${ }^{4,47}$

Conclusion. FLT3 mutations exist in a small proportion of Saudi ALL patients. Regarding clinical outcomes, there was no prognostic significance in ALL patients with or without FLT3 mutations. The observation of high frequency in hyperdiploid ALL is in agreement with similar studies from other geographical regions; however, there is a lack of association between MLL gene rearrangement and FLT3 mutations among ALL patient that may be due to the limited sample size. Further studies are needed to confirm and establish these results.

Acknowledgment. We thank Jon Johnston, Principal Clinical Scientist from Histopathology lab for editing this research article. We thank all the Hematology, Cytogenetic and Molecular Laboratories Staffs, especially Mr. Mohamed Asiri and Dalal Alkhammash from Hematology Lab for data collection and Ms Nadia Halawani from Molecular Lab for the great support in Molecular work of this study. We also thank Ms Khawla Al-Fayez from Cytogenetic Lab for excellent support and data collection in cytogenetic aspect of this study.

10. Nakao M, Janssen JWG, Erz D, Seriu T, Bartram CR. Tandem duplication of the FLT3 gene in acute lymphoblastic leukemia: a marker for the monitoring of minimal residual disease. Leukemia. 2000;14:522-524. $\quad$ http://dx.doi.org/10.1038/sj.leu.2401695 PMid:10720156

11. Armstrong SA, Kung AL, Mabon ME, et al. Inhibition of FLT3 in MLL: validation of a therapeutic target identi?ed by gene expression based classi?cation. Cancer Cell. 2003;3:173-183. http://dx.doi.org/10.1016/S1535-6108(03)00003-5

12. Armstrong SA, Mabon ME, Silverman LB, Li A, Gribben JG, Fox EA, Sallan SE, Korsmeyer SJ: FLT3 mutations in childhood acute lymphoblastic leukemia. Blood 2004, 103(9):3544-3546. http://dx.doi.org/10.1182/blood-2003-07-2441 PMid:14670924

13. Andersson A, Paulsson K, Lilljebjorn H, Lassen C, Strombeck B, Heldrup J, Behrendtz M, Johansson B, Fioretos T: FLT3 mutations in a 10 year consecutive series of 177 childhood acute leukemias and their impact on global gene expression patterns. Genes Chromosomes Cancer 2008, 47(1):64-70. http://dx.doi.org/10.1002/gcc.20508 PMid:17943971

14. Case M, Matheson E, Minto L, Hassan R, Harrison CJ, Bown N, Bailey S, Vormoor J, Hall AG, Irving JA: Mutation of genes affecting the RAS pathway is common in childhood acute lymphoblastic leukemia. Cancer Res 2008, 68(16):6803-6809. http://dx.doi.org/10.1158/0008-5472.CAN-08-0101 PMid:18701506

15. Paulsson K, Horvat A, Strombeck B, Nilsson F, Heldrup J, Behrendtz M, Forestier E, Andersson A, Fioretos T, Johansson B: Mutations of FLT3, NRAS, KRAS, and PTPN11 are frequent and possibly mutually exclusive in high hyperdiploid childhood acute lymphoblastic leukemia. Genes Chromosomes Cancer 2008, 47(1):26-33. PMid:17910045

16. Yamamoto T, Isomura M, Xu Y, Liang J, Yagasaki H, Kamachi Y, Kudo K, Kiyoi H, Naoe T, Kojma S: PTPN11, RAS and FLT3 mutations in childhood acute lymphoblastic leukemia. Leuk Res 
2006, 30(9):1085-1089

http://dx.doi.org/10.1016/j.leukres.2006.02.004 PMid:16533526

17. Braoudaki M, Karpusas M, Katsibardi K, Papathanassiou C, Karamolegou K, Tzortzatou-Stathopoulou F: Frequency of FLT3 mutations in childhood acute lymphoblastic leukemia. Med Oncol 2009, 26(4):460-462. http://dx.doi.org/10.1007/s12032-008-9146-Z PMid:19085113

18. Paietta E, Ferrando AA, Neuberg D, Bennett JM, Racevskis J, Lazarus H, Dewald G, Rowe JM, Wiernik PH, Tallman MS, Look AT. Activating FLT3 mutations in CD117/KIT(+) T-cell acute lymphoblastic leukemias. Blood. 2004 Jul 15;104(2):558-60. http://dx.doi.org/10.1182/blood-2004-01-0168 PMid:15044257

19. Yokota S, Kiyoi H, Nakao M, Iwai T, Misawa S, Okuda T et al. Internal tandem duplication of the FLT3gene is preferentially seen in acute myeloid leukemia and myelodysplastic syndrome among various hematological malignanciesA study on a large series of patients and cell lines.Leukemia 1997; 11: 1605-1609. http://dx.doi.org/10.1038/sj.leu.2400812 PMid:9324277

20. Meshinchi S, Woods WG, Stirewalt DL, Sweetser DA, Buckley JD, Tjoa TK et al. Prevalence and prognostic significance of Flt3internal tandem duplication in pediatric acute myeloid leukemia. Blood 2001; 97: 89-94. http://dx.doi.org/10.1182/blood.V97.1.89 PMid:11133746

21. Stirewalt DL, Kopecky KJ, Meshinchi S, Appelbaum FR, Slovak ML, Willman CL et al. FLT3, RAS, and TP53 mutations in elderly patients with acute myeloid leukemia. Blood 2001; 97: 3589-3595. http://dx.doi.org/10.1182/blood.V97.11.3589 PMid:11369655

22. Abu-Duhier FM, Goodeve AC, Wilson GA, Gari MA, Peake IR, Rees DC et al. FLT3internal tandem duplication mutations in adult acute myeloid leukaemia define a high risk group. Br J Haematol 2000; 111: 190-195. $\quad$ http://dx.doi.org/10.1046/j.13652141.2000.02317.x PMid:11091200

23. Kiyoi H, Naoe T, Nakano Y, Yokota S, Minami S, Miyawaki S et al. Prognostic implication of FLT3and NRAS gene mutations in acute myeloid leukemia. Blood 1999; 93: 3074-3080 PMid:10216104

24. Rombouts WJ, Blokland I, Lowenberg B, Ploemacher RE. Biological characteristics and prognosis of adult acute myeloid leukemia with internal tandem duplications in the Flt3gene. Leukemia 2000; 14: 675-683. http://dx.doi.org/10.1038/sj.leu.2401731 PMid:10764154

25. Kottaridis PD, Gale RE, Frew ME, Harrison G, Langabeer SE, Belton AA et al. The presence of a FLT3internal tandem duplication in patients with acute myeloid leukaemia (AML) adds important prognostic information to cytogenetic risk group and response to the first cycle of chemotherapy: analysis of 854 patients from the United Kingdom Medical Research Council AML 10 and 12 trials. Blood 2001; 98: 1752-1759 http://dx.doi.org/10.1182/blood.V98.6.1752 PMid:11535508

26. Gari M, Abuzenadah A, Chaudhary A, Al-Qahtani M, Banni H, Ahmad W, Al-Sayes F, Lary S, Damanhouri G. Detection of FLT3 oncogene mutations in acute myeloid leukemia using conformation sensitive gel electrophoresis. Int J Mol Sci. 2008 Nov; 9(11):2194204. http://dx.doi.org/10.3390/ijms9112194 PMid:19330068 PMCid:PMC2635624

27. Elyamany GH, Awad M, Fadalla K, Al-Balawi M, Al- Abulaaly A. Frequency and Prognostic Relevance of FLT3 Mutations in Saudi Acute Myeloid Leukemia Patients. Adv Hematol. 2014; 2014:141360. http://dx.doi.org/10.1155/2014/141360 PMid:24696688 PMCid:PMC3950551

28. Vrooman LM, Stevenson KE, Supko JG, O'Brien J, Dahlberg SE, Asselin BL, Athale UH, Clavell LA, Kelly KM, Kutok JL, Laverdière C, Lipshultz SE, Michon B, Schorin M, Relling MV, Cohen HJ, Neuberg DS, Sallan SE, Silverman LB. Postinduction dexamethasone and individualized dosing of Escherichia Coli Lasparaginase each improve outcome of children and adolescents with newly diagnosed acute lymphoblastic leukemia: results from a randomized study--Dana-Farber Cancer Institute ALL Consortium Protocol 00-01. J Clin Oncol. 2013 Mar 20;31(9):1202-10. Epub 2013 Jan 28. PubMed PMID: 23358966; PubMedCentral PMCID: PMC3595424. http://dx.doi.org/10.1200/JCO.2012.43.2070

29. Garcia-Manero G, Kantarjian HM. The hyper-CVAD regimen in adult acute lymphocytic leukemia. Hematol Oncol Clin North Am. 2000 Dec;14(6):1381-96, x-xi. Review. PubMed PMID: 11147229.

30. Schnittger S, Schoch C, Dugas M, et al. Analysisof FLT3 length mutations in 1003 patients with acute myeloid leukemia: correlation to cytogenetics,FAB subtype, and prognosis in the AMLCG study and usefulness as a marker for the detection of minimal residual disease. Blood. 2002;100:59-66 http://dx.doi.org/10.1182/blood.V100.1.59 PMid:12070009

31. Thiede C, Steudel C, Mohr B, et al. Analysis of FLT3-activating mutations in 979 patients with acute myelogenous leukemia: association with FAB subtypes and identification of subgroups with poor prognosis. Blood. 2002;99:4326- 4335

32. Carow CE, Levenstein M, Kaufmann SH, et al. Expression of the hematopoietic growth factor receptor FLT3 (STK-1/Flk2)in human leukemias. Blood.1996;87:1089-109 PMid:8562934

33. Wang W, Wang XQ, Xu XP, Lin GW. Prevalence and prognostic significance of FLT3 gene mutations in patients with acute leukaemia: analysis of patients from the Shanghai Leukaemia Cooperative Group. J Int Med Res. 2010 Mar-Apr;38(2):432-42. http://dx.doi.org/10.1177/147323001003800206 PMid:20515557

34. Xu B, Li L, Tang JH, Zhou SY.Detection of FLT3 gene and FLT3/ITD mutation by polymerase chain reaction-single-strand conformation polymorphism in patients with acute lymphoblastic leukemia. Di Yi Jun Yi Da Xue Xue Bao. 2005 Oct;25(10):120710.

35. Xu F, Taki T, Yang HW, Hanada R, Hongo T, Ohnishi H, Kobayashi M, Bessho F, Yanagisawa M, Hayashi Y. Tandem duplication of the FLT3 gene is found in acute lymphoblastic leukaemia as well as acutemyeloid leukaemia but not in myelodysplastic syndrome or juvenile chronic myelogenous leukaemia in children. Br J Haematol. 1999 Apr;105(1):155-62. http://dx.doi.org/10.1111/j.1365-2141.1999.01284.x PMid:10233379

36. Taketani T, Taki T, Sugita K, Furuichi Y, Ishii E, Hanada R, Tsuchida M, Ida K, Hayashi Y: FLT3 mutations in the activation loop of tyrosine kinase domain are frequently found in infant ALL with MLL rearrangements and pediatric ALL with hyperdiploidy. Blood 2004, 103(3):1085-1088. http://dx.doi.org/10.1182/blood2003-02-0418 PMid:14504097

37. Karabacak BH, Erbey F, Bayram I, Yilmaz S, Acipayam C, Kilinc $\mathrm{Y}$, Tanyeli A. Fms-like tyrosine kinase 3 mutations in childhood acute leukemias and their association with prognosis. Asian Pac J Cancer Prev. 2010;11(4):923-7. PMid:21133602

38. Chang P, Kang M, Xiao A, Chang J, Feusner J, Buffler P, Wiemels J. FLT3 mutation incidence and timing of origin in a population case series of pediatric leukemia. BMC Cancer. 2010 27;10:513. http://dx.doi.org/10.1186/1471-2407-10-513

39. Grossmann V, Haferlach C, Weissmann S, Roller A, Schindela S, Poetzinger F, Stadler K, Bellos F, Kern W, Haferlach T, Schnittger $\mathrm{S}$, Kohlmann A.The molecular profile of adult T-cell acute lymphoblastic leukemia: Mutations in RUNX1 and DNMT3A are associated with poor prognosis in T-ALL. Genes Chromosomes Cancer. 2013 Apr;52(4):410-22. http://dx.doi.org/10.1002/gcc.22039 PMid:23341344

40. Ishfaq M, Malik A, Faiz M, Sheikh I, Asif M, Khan MN, Qureshi MS, Zahid S, Manan A, Arooj M, Qazi MH, Chaudhary A, Alqahtani MH, Rasool M. Molecular characterization of flt3 mutations in acute leukemia patients in Pakistan. Asian Pac J Cancer Prev. 2012; 13(9):4581-5 http://dx.doi.org/10.7314/APJCP.2012.13.9.4581 PMid:23167384

41. Zhao X, Tang KJ, Tian Z, Chen LP, Mi YC, Wang JX. FLT3 mutation in patients with acute lymphoblastic leukemia and its clinical significance. Zhongguo Yi Xue Ke Xue Yuan Xue Bao. 2009 Oct;31(5):522-6. PMid:19968062

42. Al-Tonbary Y, Mansour AK, Ghazy H, Elghannam DM, AbdElghaffar HA. Prognostic significance of foetal-like tyrosine kinase 3 mutation in Egyptian children with acute leukaemia. Int J Lab Hematol. 2009 Jun; 31(3):320-6. http://dx.doi.org/10.1111/j.1751553X.2008.01039.x PMid:18336585

43. Wang L, Lin D, Zhang X, Chen S, Wang M, Wang J. Analysis of FLT3 internal tandem duplication and D835 mutations in Chinese acute leukemia patients. Leuk Res. 2005 Dec;29(12):1393-8. http://dx.doi.org/10.1016/j.leukres.2005.05.013 PMid:15996732

44. Nakao M, Yokota S, Iwai T, et al. Internal tandem duplication of the flt3 gene found in acute myeloid leukemia. Leukemia. 1996;10:1911-1918. PMid:8946930

45. Weisberg E, Barrett R, Liu Q, Stone R, Gray N, Griffin JD: FLT3 inhibition and mechanisms of drug resistance in mutant FLT3positive AML. Drug Resist Updat 2009, 12(3):81-89. 
http://dx.doi.org/10.1016/j.drup.2009.04.001 PMid:19467916

46. Hoehn D, Medeiros LJ, Chen SS, Tian T, Jorgensen JL, Ahmed Y, Lin P. CD117 expression is sensitive but nonspecific predictor of

FLT3 mutation in T acute lymphoblastic leukemia and T/myeloid acute leukemia. Am J Clin Pathol. 2012 Feb;137(2):213-9 http://dx.doi.org/10.1309/AJCPR3N3JMSYLPFG
PMid:22261446

47. Abu-Duhier FM, Goodeve AC, Wilson GA, Care RS, Peake IR, Reilly JT. Identification of novel FLT-3 Asp835 mutations in adult acute myeloid leukaemia. Br J Haematol. 2001;113: 983-988 http://dx.doi.org/10.1046/j.1365-2141.2001.02850.x PMid:11442493 